\title{
TINJAUAN PELAKSANAAN ROYA PARTIAL TERHADAP OBJEK HAK TANGGUNGAN
}

\author{
Lisa Anggraeni, Yunanto, Novira Maharani Sukma \\ Program Studi Magister Kenotariatan \\ Fakultas Hukum, Universitas Diponegoro \\ E-mail: lisaanggraeni27@yahoo.com
}

\begin{abstract}
The mortgage right giver who has paid off his obligations to the mortgage right holder, then cancels the mortgage rights on the object of the mortgage right that is charged. Article 22 paragraph (1) of the Underwriting Right Act "after the mortgage has been written off, the land office has crossed out notes on land rights and certificates". While one of the characteristics inherent in mortgage rights is that the mortgage rights charged cannot be shared, but this provision can be distorted in Article 2 paragraph (2) of the Mortgage Rights Act and implementing regulations issued, namely Regulation of the Minister of Agrarian Number 3 of 1997 which raises the existence of partial roya, which can be done with partial abolition, but the two regulations have differences between one regulation and the other this will certainly lead to legal disputes if there is no general perception about the implementation of partial roya which can ultimately harm the debtor. The purpose of this study is to describe and analyze the partial roya implementation based on the Mortgage Rights Act, Law Number 4 of 1996 and Minister of Agrarian Regulation Number 3 of 1997.
\end{abstract}

\section{Keywords : mortgage rights; partial roya}

\begin{abstract}
Abstrak
Pemberi hak tanggungan yang telah melunasi kewajibannya kepada pemegang hak tanggungan, maka hapuslah hak tanggungan atas obyek hak tanggungan yang dibebankan. Dalam Pasal 22 ayat (1) UUHT menyebutkan " setelah hak tanggungan hapus, kantor pertanahan mencoret catatan hak atas tanah dan sertipikatnya". Sementara salah satu sifat yang melekat dalam hak tanggungan yaitu hak tanggungan yang dibebankan tidak dapat dibagi-bagi, tapi ketentuan tersebut dapat disimpangi dalam Pasal Pasal 2 ayat (2) UUHT serta dikeluarkan peraturan pelaksananya yakni Peraturan Menteri Negara Agraria Nomor 3 Tahun 1997 yang memunculkan adanya roya partial yaitu dapat dilakukannya pencoretan oleh sebagian hutang tetapi kedua peraturan tersebut terdapat ketidaksesuaian antara peraturan yang satu dan yang lainnya hal ini tentu menimbulkan adanya sengketa hukum apabila tidak adanya persamaan persepsi mengenai pelaksanaan roya parsial yang pada akhirnya dapat merugikan pihak debitur. Adapun tujuan dilakukannya penelitian ini adalah untuk mendeskripsikan dan menganalisis pelaksanaan roya partial berdasarkan UUHT Nomor 4 Tahun 1996 dan Peraturan Menteri Negara Agraria Nomor 3 Tahun 1997.
\end{abstract}

\section{Kata kunci : hak tanggungan; roya partial}

\section{A. Pendahuluan}

Perkembangan zaman yang begitu pesat juga mempengaruhi kegiatan ekonomi yang ada terbukti dengan banyak orang-perorangan baik sendiri-sendiri maupun bersama-sama menjalankan bisnis dengan membuka usaha. Pembentukkan usaha tidak semudah yang 
dipikirkan selain harus memenuhi ketentuan yang sudah ditetapkan salah satu faktor yang paling berpengaruh terhadap berjalan atau tidaknya usaha dapat dilihat dari modal yang akan digunakan, semakin besar usaha yang akan dibentuk maka semakin besar pula modal yang dibutuhkan, oleh karena itu untuk mencukupi modal tersebut maka para pengusaha melakukan peminjaman uang yang sekarang sering disebut dengan kredit.

Kata kredit berasal dari bahasa Yunani, yaitu "Credere" yang berarti kepercayaan atau dalam bahasa Latin "Creditum" yang berarti kepercayaan akan kebenaran. Seseorang yang memperoleh kredit pada dasarnya orang tersebut memperoleh kepercayaan. Menurut pendapat Mulyono dalam bukunya Kasmir, berpendapat bahwa yang dimaksud dengan kredit adalah "Kemampuan untuk melaksanakan suatu pembelian atau mengadakan suatu pinjaman dengan suatu janji pembayaran akan dilakukan ditangguhkan pada suatu jangka yang disepakati (Kasmir, 2000). Adapun unsur-unsur yang terkandung dalam pemberian fasilitas kredit menurut Toman Sony Tambunan dan Wilson R.G. Tambunan antara lain (Tambunan, 2019):

1. Kepercayaan, merupakan hubungan antara pemberi kredit (bank) yang menyerahkan sejumlah dana kepada penerima kredit (nasabah) terjalin karena adanya rasa kepercayaan dalam hal ini pemberi kredit memiliki keyakinan bahwa prestasi yang diberikan akan dilunasi oleh penerima kredit dalam jangka waktu tertentu

2. Jangka waktu, adanya unsur jangka waktu yang telah ditetapkan bersama mengenai pemberian dan pelunasan kredit. Dalam unsur jangka waktu ini terkandung nilai "agio" dari suatu uang yaitu nilai uang saat ini akan lebih tinggi dari nilai uang yang akan diterima di masa yang akan dating

3. Resiko, yaitu dalam pemeberian kredit akan memiliki resiko yang tinggi dari pihak penerima kredit untuk dapat menghindari resiko buruk yang mungkin terjadi dalam hal pemberian dan perjanjian kredit maka dari itu perlu diikat dengan agunan sebagai bentuk jaminan dari pihak peminjam

4. Prestasi, dimana suatu objek yang harus dipenuhi oleh penerima kredit atas perjanjian, prestasi ini dapat berupa barang atau imbalan jasa yang telah disepakati bersama antara pemberi dan penerima kredit

Dalam prakteknya, pemberian kredit kepada debitur atau nasabah oleh suatu bank memerlukan suatu jaminan dari debitur, baik jaminan itu suatu barang bergerak maupun tidak bergerak yang terpenting barang tersebut mempunyai nilai, sehingga apabila terjadi wanprestasi dalam hal tidak terpenuhinya kewajiban dari debitur atau debitur tidak dapat mengembalikan kredit sesuai dengan waktu yang telah diperjanjikan oleh kedua belah pihak, maka pihak kreditur dapat menjual barang jaminan yang telah dijaminkan kepada pihak bank baik melalui lelang 
mauun penjualan di bawah tangan, sehingga hasil penjualan barang jaminan tersebut dapat dipergunakan untuk melunasi hutang-hutang debitur dan apabila terdapat sisa dari hasil penjualan barang jaminan, sisa tersebut akan dikembalikan kepada debitur. Sifat barang jaminan tersebut hanya digunakan kreditur untuk menjaga terjadinya wanprestasi oleh pihak debitur. Dalam hal debitur telah melunasi seluruh kewajibannya maka objek barang yang menjadi jaminan akan dikembalikan kepada debitur.

Adrian Sutedi membedakan jaminan menjadi dua yaitu jaminan yang lahir dari undang-undang yaitu jaminan umum dan jaminan yang lahir karena perjanjian (Sutedi, 2010). Jaminan umum adalah jaminan yang adanya telah ditentukan Undang-Undang, Contohnya adalah pada Pasal 1311 KUHPerdata, Pasal 1232 KUHPerdata, dan Pasal 1311 KUHPerdata yang menyatakan bahwa kekayaan Debitur, baik berupa benda bergerak dan tidak bergerak, yang telah ada dan yang akan datang dikemudian hari walaupun tidak diserahkan sebagai jaminan, maka akan secara hukum menjadi jaminan seluruh utang Debitur. Sedangkan jaminan khusus adalah jaminan yang timbul karena adanya perjanjian terlebih dahulu, yaitu perjanjian yang ada antara Debitur dengan pihak perbankan atau pihak ketiga yang menanggung utang Debitur. Jaminan khusus terdiri dari jaminan yang bersifat perseorangan dan jaminan yang bersifat kebendaan. Jaminan kebendaan memberikan hak mendahului atas benda-benda tertentu dan mempunyai sifat yang melekat dan mengikuti benda yang bersangkutan, sedangkan jaminan perseorangan bersifat tidak memberikan hak mendahului atas benda-benda tertentu tetapi hanya terbatas pada harta kekayaan seseorang lewat orang yang menjamin pemenuhan yang bersangkutan (Salim, 2007).

Secara formal, pembebanan jaminan hak atas tanah berlaku ketentuan-ketentuan yang terdapat dalam Undang-undang Nomor 5 Tahun 1960, tetapi secara materiil, yaitu yang berkaitan dengan hak dan kewajiban para pihak berlaku ketentuan yang terdapat dalam Buku II KUH Perdata dan Credietverband. Tetapi sejak diundangkannya Undang-undang Nomor 4 Tahun 1996 tentang Hak Tanggungan selanjutnya disebut UUHT, maka dualisme dalam pembebanan hak atas tanah kini tidak lagi kita kenal, Pengertian hak tanggungan didasarkan pada Pasal 1 ayat (1) UUHT menyatakan bahwa hak jaminan yang dibebankan pada hak atas tanah sebagaimana yang dimaksud dalam Undang-Undang No. 5 Tahun 1960 tentang Peraturan Dasar Pokok-Pokok Agraria berikut atau tidak berikut benda-benda lain yang merupakan satu kesatuan dengan tanah itu untuk pelunasan hutang tertentu, yang memberikan kedudukan yang diutamakan kepada kreditor tertentu terhadap kreditor-kreditor lainnya.

Hak tanggungan adalah penguasaan hak atas tanah, berisi kewenangan bagi kreditur untuk berbuat sesuatu mengenai tanah yang dijadikan agunan, tetapi bukan untuk dikuasai secara fisik 
dan digunakan, melainkan untuk menjualnya jika debitur cidera janji dan mengambil dari hasilnya seluruhnya atau sebagian pembayaran lunas utang debitur kepadanya (Harsono, 2008). Dari Pasal 1 tersebut diatas dapat diketahui bahwa jika debitur cedera janji, kreditur pemegang hak tanggungan berhak menjual melalui pelelangan umum tanah yang dijadikan jaminan menurut ketentuan peraturan perundang-undangan yang bersangkutan dengan hak mendahului daripada kreditor-kreditor lain. Kedudukan diutamakan tersebut diatur dalam Pasal 1134 Kuhper yang menyatakan gadai dan hipotik lebih tinggi daripada hak istimewa kecuali Undang-Undang menentukan sebaliknya dikarenakan gadai dan hipotik bersumber dari perjanjian, berdasarkan Pasal 1138 Kuhper dinyatakan bahwa perjanjian itu mengikat sebagai Undang-Undang bagi yang membuatnya sehingga dianggap jebih tinggi daripada hak istimewa tetapi juga ada beberapa pengecualiaan yang menyatakan bahwa hak istimewa lebih tinggi daripada gadai dan hipotik yakni dalam ketentuan piutang negara yang harus didahulukan dibandingkan dengan kreditor lainnya tersebut, maka dasar hukumnya dapat diketemukan dalam UU Nomor 9 Tahun 1994 tentang Perubahan UU Nomor 6 Tahun 1983 tentang Ketentuan Umum dan Tata Cara Perpajakan dijumpai ketentuan yang menentukan tagihan pajak mempunyai hak mendahului lainnya. Hal ini sesuai Pasal 21 UU Nomor 9 Tahun 1994 dinyatakan bahwa:

Hak mendahulu tagihan pajak melebihi segala hak mendahulu lainnya kecuali terhadap:

1. biaya perkara yang semata-mata disebabkan suatu penghukuman untuk melelang suatu barang;

2. biaya yang telah dikeluarkan untuk menyelamatkan suatu barang;

3. biaya perkara yang semata-mata disebabkan pelelangan dan penyelesaian suatu warisan.

Hak tanggungan sebagai lembaga jaminan muncul dengan terlebih dahulu diadakan perjanjian pokok. Perjanjian pokok sendiri merupakan perjanjian utama yang dilakukan oleh debitur dengan lembaga perbankan maupun lembaga keuangan non bank yang diperuntukkan untuk mendapatkan fasilitas kredit dari lembaga keuangan Salah satu bentuk perjanjian pokok yang timbul sebelum ada penjaminan adalah perjanjian kredit. Setelah dilakukan perjanjian pokok maka akan dilanjutkan dengan perjanjian accessoir atau perjanjian ikutan, dimana perjanjian accessoir bersifat melekat dengan perjanjian pokoknya sehingga apabila perjanjian pokoknya telah usai maka secara otomatis perjanjian accesoir juga telah berakhir, begitu juga apabila perjanjian pokoknya berpindah maka perjanjian accesoir-nya ikut pula berpindah yakni berupa penjaminan objek hak tanggungan milik nasabah bank yang berkedudukan sebagai debitur. Perjanjian accessoir jaminan hak tanggungan dilakukan untuk menjamin pelunasan kredit. Sehingga kreditor tidak dirugikan ketika debitur melakukan wanprestasi. Maka dari itu 
aturan hukum sangat diperlukan untuk pelaksanaan pembebanan hak tanggungan yang dituangkan dalam perjanjian kredit dengan tujuan memberikan kepastian dan perlindungan hukum bagi pihak-pihak terkait khususnya bagi kreditur apabila debitur wanprestasi atau tidak memenuhi kewajibannya. (Risa, 2017).

Bagi pemberi hak tanggungan yang telah melunasi kewajibannya kepada pemegang hak tanggungan, maka hapuslah hak tanggungan atas obyek hak tanggungan yang dibebankan. Dalam Pasal 22 ayat (1) UUHT menyebutkan " setelah hak tanggungan hapus, kantor pertanahan mencoret catatan hak atas tanah dan sertipikatnya". Sementara salah satu sifat yang melekat dalam hak tanggungan yaitu hak tanggungan yang dibebankan tidak dapat dibagi-bagi, hal ini sesuai dengan ketentuan dalam Pasal 2 ayat (1) UUHT yang dijelaskan secara terperinci dalam penjelasan Pasal 2 ayat (1) UUHT :

bahwa hak tanggungan membebani secara utuh terhadap objek hak tanggungan dan setiap bagian dari padanya. Telah dilunasinya sebagian utang yang dijamin tidak berarti membebaskan sebagian objek hak tanggungan dari beban hak tanggungan, melainkan hak tanggungan tetap membebani seluruh objek hak tanggungan untuk sisa utang yang belum dibayar. Adanya pengaturan tersebut mempersulit debitur apabila tanah yang menjadi objek jaminan tersebut terdiri lebih dari 1 bidang tanah tetapi dibebankan terhadap 1 hak tanggungan saja sementara utang tersebut baru dilunasi sebagian maka debitur baru dapat memiliki objek jaminan tersebut setelah melunasi semua kewajibannya. Namum jika dilihat sifat yang tidak dapat dibagi-bagi dari hak tanggungan dapat disimpangi seperti yang tertuang dalam Pasal 2 ayat (2) UUHT dengam syarat bahwa : hak tanggungan dibenbankan pada beberapa hak atas tanah, diperjanjikan dalam akta pembebanan hak tanggungan, pelunasan utang yang dijamin dengan cara angsuran yang besarnya sama dengan nilai masing-masing hak atas tanah merupakan bagian dari objek hak tanggungan, yang akan dibebaskan dari hak tanggungan tersebut yang berarti hak tanggungan tersebut hanya membebani sisa objek tanggungan yang belum dilunasi (Arnowo, 2017). Tetapi hal tersebut bertentangan dengan Peraturan Menteri Negara Agraria/ Kepala Badan Pertanahan Nasional Nomor 3 Tahun 1997 tentang Ketentuan Pelaksanaan Peraturan Pemerintah Nomor 24 Tahun 1997 tentang Pendaftaran Tanah, Pasal 124 ayat (1) dan ayat (2), yang menyatakan :

1) Pendaftaran hapusnya hak tanggungan atas sebagian obyek hak tanggungan dapat dilakukan berdasarkan pelunasan sebagian utang yang dijamin, dengan ketentuan bahwa :

a) obyek hak tanggungan terdiri dari beberapa hak

b) kemungkinan hapusnya sebagian hak tanggungan karena pelunasan sebagian utang tersebut diperjanjikan di dalam akta pemberian hak tanggungan. 
2) Pendaftaran hapusnya hak tanggungan atas sebagian obyek hak tanggungan juga dapat dilakukan walaupun tidak memenuhi ketentuan tersebut diatas berdasarkan pelepasan hak tanggungan atas sebagian obyek hak tanggungan oleh pemegang hak tanggungan yang dituangkan dalam akta otentik atau surat pernyataan dibawah tangan dengan mencantumkan secara jelas bagian dari obyek hak tanggungan yang dibebaskan dari beban hak tanggungan.

Dari kedua peraturan tersebut dapat dilihat terdapat ketidaksesuaian antara peraturan yang satu dan yang lainnya hal ini tentu menimbulkan adanya sengketa hukum apabila tidak adanya persamaan persepsi mengenai pelaksanaan roya parsial yang pada akhirnya dapat merugikan pihak debitur ditambah lagi dengan dikeluarkannya

Teori yang akan digunakan untuk menganalisis permasalahan dalam penelitian ini adalah teori Stufenbau Dalam teorinya tentang hierarki norma Hans Kalsen menempatkan grundnorms sebagai puncak dari norma-norma yang kemudian disusul oleh norma yang lebih rendah.melalui hubungan yang bersifat superior dan inferior maka selanjutnya norma yang paling tinggi akan dikonkretkan dalam norma yang lebih rendah sampai kepada norma yang paling konkret. Norma hukum itu berjenjang-jenjang dan berlapis-lapis dalam suatu hierarki tata susunan, di mana suatu nora yang lebih rendah berlaku, bersuber dan berdasar pada norma yanng lebih tinggi, norma yang lebih tinggi berlaku, bersumber pada norma yang lebih tinggi lagi, demikian seterusnya sampai pada norma yang tidak dapt ditelusuri lebih lanjut dan bersifat hipotesis dan fiktif, yaitu norma dasar (Soeprapto, 1998).

Berdasarkan uraian di atas maka permasalahan yang dapat disusun antara lain :

Bagaimana pelaksanaan roya parsial berdasarkan UUHT Nomor 4 Tahun 1996 dan Peraturan Menteri Negara Agraria Nomor 3 Tahun 1997

Penelitian ini berfokus pada pelaksanaan roya partial terhadap hak tanggungan sebagaimana juga sudah pernah dijelaskan, seperti oleh Mega Ria Sagita di tahun 2016 dimana penelitiannya berfokus pada pelaksanaan roya partial hak tanggungan menurut Undang-Undang 4 tahun 1996 tentang hak tanggungan di kantor pertanahan Kota Semarang (Sagita, 2016), Kerenandrie Pradnya Kinanti tahun 2012 yang mana peneitiannya berfokus pada roya partial terhadap jaminan hak tanggungan dalam praktek di kantor pertanahan kota Semarang(Kinanti, 2012), Efty Hindaru Sudibyo di tahun 2017 yang mana penelitiannya berfokus pada peran notaris dala pembuatan akta izin roya hak tanggungan karena hapusnya hutang dalam perpektif kepastian hukum. (Sudibyo, 2017)

Berdasarkan tulisan tersebut diatas terdapat perbedaan fokus penelitian yang akan dilakukan penulis dengan penelitian yang sudah ada, walapun sama-sama membahas mengenai 
roya partial dan hak tanggungan namum penulis menekankan pada analisa Pelaksanaan roya partial terhadap objek hak tanggungan berdasarkan Undang-Undang Nomor 4 Tahun 1996 dan Peraturan Menteri Negara Agraria Nomor 3 Tahun 1997 yang mana terdapat ketidaksesuaian pengaturan yang mengatur mengenai roya partial.

\section{B. Metode Penelitian}

Tipe penelitian yang digunakan dalam penelitian ini adalah Yuridis Normatif Menurut Soerjono Soekanto tipe penelitian yuridis normatif yaitu penelitian hukum yang dilakukan dengan cara meneliti bahan pustaka atau data sekunder sebagai bahan dasar untuk diteliti dengan cara mengadakan penelusuran terhadap peraturan-peraturan dan literatur-literatur yang berkaitan dengan permasalahan yang diteliti (Mamudji, 2001). Sedangkan pendekatan yang akan dipakai dalam penelitian ini adalah pendekatan perundang-undangan menurut Peter Mahmud Marzuki pendekatan Undang-Undang dilakukan dengan menelaah semua UndangUndang dan regulasi yang bersangkut paut dengan isu hukum (Marzuki, 2011) yang ditangani dalam hal ini terkait dengan pelaksanaan roya parsial dimana pendekatan Undang-Undang ini membuka kesempatan bagi peneliti untuk dapat mempelajari apakah ada konsistensi antara Undang-Undang dengan Undang-Undang lainya atau Undang-Undang dengan regulasi lainnya dimana hasil dari telaah tersebut merupakan suatu argumen untuk memecahkan isu yang sedang dihadapi. Data dalam penulisan ini adalah data sekunder, yaitu bahan pustaka yang mencakup dokumen-dokumen resmi, buku-buku perpustakaan peraturan perundang-undangan, karya ilmiah, artikel-artikel, serta dokumen yang berkaitan dengan materi penelitian. Data sekunder sendiri terdiri atas terdiri dari bahan hukum primer, bahan hukum sekunder, dan bahan hukum tersier. Spesifikasi penelitian yang digunakkan dalam penelitian ini adalah deskriptif analitis Deskriptif analitis artinya peneliti dalam menganalisis berkeinginan untuk memberikan gambaran atau pemaparan atas subjek dan objek penelitian berdasarkan hasil penelitian (Achmad, 2013) Penulis mendeskripsikan fokus penelitian kemudian melakukan analisis terhadap fokus penelitian tersebut. Penulis memaparkan hasil penelitian yang diberikan tidak menggunakan angka-angka melainkan suatu bentuk tulisan-tulisan dari deskripsi. Metode pengumpulan data dalam penelitian ini dilakukan dengan studi pustaka, yaitu suatu cara pengumpulan data dengan melakukan penelusuran dan menelaah bahan pustaka (literatur, hasil penelitian, majalah ilmiah, buletin ilmiah, jurnal ilmiah, peraturan perundang-undangan). Analisis data merupakan kegiatan dalam penelitian untuk melakukan kajian terhadap hasil pengolahan data. Penulis melakukan analisis data dengan menggunakan teori-teori yang telah didapatkan sebelumnya. Teknik analisis data yang digunakan dalam penelitian ini adalah 
analisis data kualitatif. Analisis data kualitatif merupakan analisis data yang tidak menggunakan angka-angka tetapi memberikan penjelasan dengan kata-kata, kalimat atas temuan-temuan dalam penelitian dan penulis menentukan isi atau makna aturan hukum yang dijadikan rujukan dalam menyelesaikan permasalahan hukum yang menjadi objek kajian (Taufani, 2018) Dalam penelitian ini penulis bermaksud mendiskripsikan dan menganalisis mengenai pengaturan pelakasanaan roya partial yang didasarkan pada dua aturan yang saling tumpang tindih dengan dibantu teori yang ada

\section{B. Hasil Dan Pembahasan}

Pelaksanaan roya partial berdasarkan UUHT Nomor 4 Tahun 1996 dan Peraturan Menteri Negara Agraria Nomor 3 Tahun 1997

\section{Proses pembebanan hak tanggungan}

Pembebanan hak tanggungan yang diatur dalam UUHT ada beberapa hal yang perlu diperhatikan yang membedakan hak tanggungan dengan lembaga jaminan yang ada sebelum dikeluarkannya undang-undang tersebut. Salah satu diantaranya ialah pencantuman "bendabenda yang ada diatasnya yang berkaitan dengan tanah" dalam pembebanannya. Sebagaimana diketahui Hukum Tanah Nasional didasarkan pada hukum adat yang menggunakan asas pemisahan horisontal, dimana benda-benda yang berada di atas tanah bukan merupakan satu kesatuan dengan tanahnya. Oleh karena itu setiap perbuatan hukum mengenai hak-hak atas tanah, tidak dengan sendirinya meliputi benda-benda tersebut. Namun demikian penerapan asas-asas hukum adat tidaklah mutlak, melainkan selalu memperhatikan dan disesuaikan dengan perkembangan kenyataan dan kebutuhan masyarakat yang dihadapinya. Pembebanan hak tanggungan atas tanah dimungkinkan pula meliputi benda-benda yang ada di atasnya sepanjang benda-benda tersebut merupakan satu kesatuan dengan tanah yang bersangkutan. Pasal 4 ayat (4) dan ayat (5) UUHT menentukan bahwa obyek hak tanggungan dapat meliputi bangunan, tanaman, dan hasil karya yang merupakan satu kesatuan dengan tanah.Namun dalam kenyataan di atas tanah yang bersangkutan sering terdapat benda berupa bangunan, tanaman maupun hasil karya lain secara tetap merupakan satu kesatuan dengan tanah yang dijadikan jaminan tersebut (Parlindungan, 1996). Benda-banda tersebut dalam prakteknya juga diterima sebagai jaminan kredit bersama-sama dengan tanah yang bersangkutan, bahkan tidak ada pemberian hak tanggungan yang hanya mengenai tanah saja, sedangkan di atas tanah tersebut ada bangunannya. Dalam Pasal 4 ayat (4) UUHT dan ayat (5) memberikan penegasan bahwa pembebanan hak tanggungan atas tanah dimungkinkan meliputi benda-benda tersebut, seperti yang sudah dilakukan dan dibenarkan 
dalam praktek selama ini. Untuk tetap berdasarkan pada asas pemisahan horizontal, pembebanan atas bangunan, tanaman dan hasil karya tersebut harus secara tegas dinyatakan (diperjanjikan) dalam akta pemberian hak tanggungan atas tanah yang bersangkutan. Proses pembebanan hak tanggungan dilaksanakan dalam dua tahap, yaitu sebagai berikut (Sudrajat, 1997):

a. Tahap pemberian hak tanggungan

Pemberian hak tanggungan wajib dilakukan sendiri oleh pemberi hak tanggungan dengan cara hadir dihadapan PPAT, apabila karena sesuatu sebab ia tidak dapat hadir sendiri di hadapan PPAT, ia wajib menunjuk pihak lain sebagai kuasanya, dengan surat kuasa membebankan hak tanggungan yang berbentuk akta autentik (Sutedi, Hukum Perizinan Dalam Sektor Pelayanan Publik , 2010) surat kuasa pembebanan hak tanggungan diatur dalam Pasal 15 ayat (1) UUHT. SKMHT ini merupakan surat kuasa khusus yang ditujukan kepada pemegang hak tanggungan atau pihak lain untuk mewakili diri pemberi hak tanggungan hadir di hadapan PPAT untuk melakukan pembebanan hak tanggungan, berhubung pemberi hak tanggungan tidak dapat datang menghadap sendiri untuk melakukan tindakan membebankan hak tanggungan di hadapan PPAT (Usman, 2008).

Tahap pembebanan hak tanggungan didahului dengan janji akan memberikan hak tanggungan sebagai jaminan pelunasan utang. Menurut Pasal 10 Ayat (1) UUHT, janji tersebut wajib dituangkan dan merupakan bagian yang tidak dapat dipisahkan dari perjanjianperjanjian piutang. Sedangkan menurut pasal 10 Ayat (2) Undang-undang hak tanggungan, "pemberian hak tanggungan dilakukan dengan akta pemberian hak tanggungan oleh PPAT sesuai dengan peraturan perundang-undangan yang berlaku". Di dalam pasal 11 ayat (1) UUHT disebutkan bahwa di dalam akta pemberian hak tanggungan wajib dicantumkan dalam hal ini berupa: nama dan identitas pemegang dan pemberi hak tanggungan;domisili pihak-pihak dan apabila di antara mereka ada yang berdomisili di luar Indonesia, baginya harus pula dicantumkan suatu domisili pilihan di Indonesia, dan dalam hal domisili pilihan itu tidak dicantumkan, kantor PPAT tempat pembuatan akta pemberian hak tanggungan dianggap sebagai domisili yang dipilih; penunjukan secara jelas utang atau utang-utang yang dijamin;nilai tanggungan;uraian yang jelas mengenai obyek hak tanggungan.

Di dalam pasal 11 ayat (2) disebutkan bahwa dalam akta pemberian hak tanggungan dapat dicantumkan janji-janji, antara lain: 
1. janji yang membatasi kewenangan pemberi hak tanggungan untuk menyewakan obyek hak tanggungan dan/atau menentukan atau mengubah jangka waktu sewa dan/atau menerima uang sewa di muka, kecuali dengan persetujuan tertulis lebih dahulu dari pemegang hak tanggungan;

2. janji yang membatasi kewenangan pemberi hak tanggungan untuk mengubah bentuk atau tata susunan obyek hak tanggungan, kecuali dengan persetujuan tertulis lebih dahulu dari pemegang hak tanggungan;

3. janji yang memberikan kewenangan kepada pemegang hak tanggungan untuk mengelola obyek hak tanggungan berdasarkan penetapan ketua pengadilan negeri yang daerah hukumnya meliputi letak obyek hak tanggungan apabila debitor sungguh-sungguh cidera janji;

4. janji yang memberikan kewenangan kepada pemegang hak tanggungan untuk menyelamatkan obyek hak tanggungan, jika hal itu diperlukan untuk pelaksanaan eksekusi atau untuk mencegah menjadi hapusnya atau dibatalkannya hak yang menjadi obyek hak tanggungan karena tidak dipenuhi atau dilanggarnya ketentuan UndangUndang;

5. janji bahwa pemegang hak tanggungan pertama mempunyai hak untuk menjual atas kekuasaan sendiri obyek hak tanggungan apabila debitor cidera janji;

6. janji yang diberikan oleh pemegang hak tanggungan pertama bahwa obyek hak tanggungan tidak akan dibersihkan dari hak tanggungan;

7. janji bahwa pemberi hak tanggungan tidak akan melepaskan haknya atas obyek hak tanggungan tanpa persetujuan tertulis lebih dahulu dari pemegang hak tanggungan;

8. janji bahwa pemegang hak tanggungan akan memperoleh seluruh atau sebagian dari ganti rugi yang diterima pemberi hak tanggungan untuk pelunasan piutangnya apabila obyek hak tanggungan dilepaskan haknya oleh pemberi hak tanggungan atau dicabut haknya untuk kepentingan umum;

9. janji bahwa pemegang hak tanggungan akan memperoleh seluruh atau sebagian dari uang asuransi yang diterima pemberi hak tanggungan untuk pelunasan piutangnya, jika obyek hak tanggungan diasuransikan;

10. janji bahwa pemberi hak tanggungan akan mengosongkan obyek hak tanggungan pada waktu eksekusi hak tanggungan.

Menurut penjelasan Pasal 11 ayat (2) tersebut, janji-janji yang disebut dalam ayat (2) tersebut sifatnya fakultatif dan tidak mempunyai pengaruh terhadap sahnya akta. 
Pihak-pihak bebas menentukan untuk menyebutkan atau tidak menyebutkan janji-janji tersebut dalam APHT. Dengan dimuatnya janji-janji tersebut dalam APHT yang kemudian didaftarkan pada Kantor Pertanahan, janji-janji tersebut juga mempunyai kekuatan mengikat terhadap pihak ketiga. Walaupun sifatnya fakultatif dan tidak mempunyai pengaruh terhadap sahnya akta dan mengingat janji-janji itu kebanyakan diberikan untuk melindungi kepentingan kreditor, maka dicantumkan atau tidaknya janji itu sangat tergantung pada peran aktif dari kreditor pada saat penandatanganan APHT dihadapan PPAT.

\section{a. Tahap Pendaftaran Hak Tanggungan}

Pemberian hak tanggungan yang dituangkan dalam APHT harus diikuti dengan kewajiban pendaftaran dengan cara dibukukan dalam kantor Pertanahan yang sekaligus menentukan saat lahirnya hak tanggungan. Pemberian hak tanggungan harus didaftarkan 7 hari kerja setelah penandatanganan APHT. Pendaftaran hak tanggungan dilakukan oleh kantor pertanahan dengan membuat buku tanah hak tanggungan dan mencatatnya dalam buku tanah hak atas tanah yang menjadi obyek hak tanggungan serta menyalin catatan tersebut pada sertipikat hak atas tanah yang bersangkutan. Menurut ketentuan pasal 14 ayat (1) UUHT dijelaskan bahwa sebagai bukti adanya hak tanggungan, Kantor Pertanahan menerbitkan sertipikat hak tanggungan. Hal ini berarti sertipikat hak tanggungan merupakan bukti adanya hak tanggungan. Oleh karena itu maka sertipikat hak tanggungan dapat membuktikan kapan lahirnya hak tanggungan yang dapat dilihat pada tanggal pendaftaran atau pencatatannya dalam buku tanah hak tanggungan.

Setelah debitur melunasi kewajibannya kepada kreditur/kreditur melepaskan hak tanggungan yang bersangkutan maka perjanjian kredit yang dibuatnya hapus demikian pula perjanjian pembebanan hak tanggunngannya pun ikut hapus mengingat hak tanggungan yang merupakan hak kebendaan maka perjanjian accessoirnya bersifat melekat dengan perjanjian pokok sehingga apabila perjanjian pokoknya telah hapus maka secara otomatis perjanjian accesoir juga telah berakhir oleh karena itu terhadap hapusnya hak tanggungan harus pula disertai dengan penghapusan pencatatannya dalam buku tanah hak atas tanah yang menjadi objek hak tanggungan. Hal ini karena apabila hal tersebut tidak dilakukan maka pihak ketiga tidak akan pernah mengetahui bahwa hak tanggungan itu telah hapus serta untuk tercapainya tertib administrasi. Dalam Pasal 22 UUHT dinyatakan bahwa : Permohonan pencoretan tersebut diajukan oleh pihak yang berkepentingan dengan melampirkan sertipikat hak tanggungan yang telah diberi catatan oleh kreditur bahwa hak tanggungan hapus karena piutang yang dijamin pelunasannya dengan hak tanggungan itu 
sudah lunas, atau pernyataan tertulis dari kreditur bahwa hak tanggungan telah hapus karena piutang itu telah lunas atau karena kreditur melepaskan hak tanggungan yang bersangkutan. Apabila kreditur tidak bersedia memberikan pernyataan tertulis tersebut, pihak yang berkepentingan dapat mengajukan permohonan perintah pencoretan kepada ketua pangadilan negeri yang daerah hukumnya tempat hak tanggungan yang bersangkutan didaftar. Permohonan pencatatan hak tanggungan berdasarkan perintah pengadilan negeri tersebut diajukan kepada kepala kantor pertanahan dengan melampirkan salinan penetapan atau putusan pengadilan negeri yang bersangkutan. Kantor pertanahan melakukan pencoretan catatan hak tanggungan menurut tata cara yang ditentukan dalam peraturan perundangundangan yang berlaku dalam waktu 7 hari kerja terhitung sejak diterimanya permohonan. Apabila pelunasan utang dilakukan dengan cara angsuran maka hapusnya hak tanggungan pada bagian obyek hak tanggungan yang bersangkutan dicatat pada buku tanah dan sertipikat hak tanggungan serta pada buku tanah dan sertipikat hak atas tanah yang telah bebas dari hak tanggungan yang semula membebaninya.

Salah satu sifat yang melekat dalam hak tanggungan yaitu hak tanggungan yang dibebankan tidak dapat dibagi-bagi(Sagita, 2016), hal ini sesuai dengan ketentuan dalam Pasal 2 ayat (1) UUHT yang dijelaskan secara terperinci dalam penjelasan Pasal 2 ayat (1) UUHT bahwa hak tanggungan membebani secara utuh terhadap objek hak tanggungan dan setiap bagian dari padanya. Telah dilunasinya sebagian utang yang dijamin tidak berarti membebaskan sebagian objek hak tanggungan dari beban hak tanggungan, melainkan hak tanggungan tetap membebani seluruh objek hak tanggungan untuk sisa utang yang belum dibayar. Namum jika dilihat sifat yang tidak dapat dibagi-bagi dari hak tanggungan dapat disimpangi seperti yang tertuang dalam Pasal 2 ayat (2) UUHT menyatakan bahwa : hak tanggungan dibenbankan pada beberapa hak atas tanah, diperjanjikan dalam akta pembebanan hak tanggungan, pelunasan utang yang dijamin dengan cara angsuran yang besarnya sama dengan nilai masing-masing hak atas tanah merupakan bagian dari objek hak tanggungan, yang akan dibebaskan dari hak tanggungan tersebut yang berarti hak tanggungan tersebut hanya membebani sisa objek tanggungan yang belum dilunasi. Tetapi dalam prakteknya terdapat kesulitan penerapan pasal tersebut karena masih ada yang tidak memuat adanya perjanjian roya parsial dalam akta pembebanan hak tanggungan maka untuk memudahkan dalam pelaksanaan roya partial tersebut keluarlah peraturan pelaksananya yakni Peraturan Menteri Negara Agraria/ Kepala Badan Pertanahan Nasional Nomor 3 Tahun 1997 tentang Ketentuan Pelaksanaan Peraturan Pemerintah Nomor 24 
Tahun 1997 tentang Pendaftaran Tanah, Pasal 124 ayat (2), yang menyatakan : Pendaftaran hapusnya hak tanggungan atas sebagian obyek hak tanggungan juga dapat dilakukan walaupun tidak memenuhi ketentuan tersebut diatas berdasarkan pelepasan hak tanggungan atas sebagian obyek hak tanggungan oleh pemegang hak tanggungan yang dituangkan dalam akta otentik atau surat pernyataan dibawah tangan dengan mencantumkan secara jelas bagian dari obyek hak tanggungan yang dibebaskan dari beban hak tanggungan

Dari kedua aturan tersebut jika dikaji berdasarkan teori Stufenbau oleh Hans Kelsen disebutkan bahwa peraturan perundang-undangan yang lebih rendah tidak boleh bertentangan dengan peraturan yang lebih tinggi. Dapat dilihat dari Susunan hierarki sebagai perwujudan norma positif Indonesia yang terdapat dalam Pasal 7 Undang-Undang No. 12 Tahun 2011 tentang Pembentukan Peraturan Perundang-Undangan bahwa jenis dan hierarki peraturan perundang-undangan terdiri atas:

1. Undang-Undang Dasar Negara Republik Indonesia Tahun 1945

2. Ketetapan Majelis Permusyawaratan Rakyat

3. Undang-Undang/ Peraturan Pemerintah Pengganti Undang-Undang

4. Peraturan Pemerintah

5. Peraturan Presiden

6. Peraturan Daerah Provinsi

7. Peraturan Daerah Kabupaten/ Kota

Jika dilihat dari tata urutan peraturan perundang-undangan Peraturan Menteri Negara Agraria Nomor 3 Tahun 1997 tersebut bukan merupakan bagian dari tata urutan peraturan perundang-undangan namun jika dilihat lebih lanjut dalam Pasal 8 Undang-Undang Nomor 12 Tahun 2011 disebutkan bahwa: "Jenis peraturan perundangan selain yang tertulis diatas mencakup peraturan yang ditetapkan oleh Majelis Permusyawaratan Rakyat, Dewan Perwakilan Rakyat, Dewan Perwakilan Daerah, Mahkamah Agung, Mahkamah Konstitusi, Badan Pemeriksa Keuangan, Komisi Yudisial, Bank Indonesia, Menteri, Badan, Lembaga atau komisi yang setingkat yang dibentuk dengan undang undang atau pemerintah atas perintah undang-undang, DPRD Provinsi, Gubernur, DPRD Kabupaten/Kota, Bupati/Walikota, Kepala desa atau setingkat dimana peraturan perundang-undangan tersebut diakui keberadaanya dan mempunyai kekuatan hukum mengikat sepanjang diperintah oleh peraturan perundang-undangan yang lebih tinggi atau dibentuk berdasarkan kewenangan". 
Dari pengaturan tersebut dapat dilihat mengenai kewenangan menteri dalam pembentukan peraturan perUndang-Undangan pada dasarnya ada dua jenis peraturan perundang-undangan yang dapat ditetapkan oleh menteri, yaitu peraturan menteri dan keputusan menteri. Oleh karena menteri adalah pembantu presiden. Maka para menteri menjalankan kewenangan pemerintahan di bidangnya masing-masing berdasarkan delegasian wewenang dari Presiden (Ranggawidjaja, 1998).maka Peraturan Menteri Negara Agraria Nomor 3 Tahun 1997 sebagai peraturan yang lebih rendah dari UUHT, seharusnya tidak bertentangan dengan peraturan diatasnya sesuai dengan asas lex superior derogate legi inferiori, yang berarti bahwa ketentuan dibawahnya tidak boleh bertentangan dengan ketentuan diatasnya. Mengingat masih adanya akta pembebanan hak tanggungan yang tidak mencantumkan klausula roya partial. hal tersebut menimbulkan masalah ketika debitur telah melunasi sebagian hutangnya kepada kreditur meskipun oleh pihak kreditur telah mengeluarkan surat keterangan roya partial hak tanggungan, namun pelaksanaan roya partial tersebut akan ditolak oleh kantor pertanahan karena pihak kreditur tidak memberikan perincian nilai dari masing-masing tanah yang menjadi obyek hak tanggungan. Dalam pembuatan akta pembebanan hak tanggungan antara pihak kreditur dengan pihak debitur didasarkan pada akta pengakuan hutang artinya apabila dalam akta pengakuan hutang tersebut diperinci mengenai nilai masing-masing dari obyek hak tanggungan, maka dengan sendirinya akta pembebanan hak tanggungan akan menyebut pula nilai dari masing-masing obyek hak tanggungan tersebut yang selanjutnya di jadikan sebagai dasar pelaksanaan roya partial, sedangkan apabila tidak dirinci maka secara otomatis juga tidak dimungkinkan untuk melaksanakan roya partial.

\section{Simpulan}

Berdasarkan teori Stufenbau oleh Hans Kelsen Peraturan Menteri Negara Agraria Nomor 3 Tahun 1997 sebagai peraturan yang lebih rendah dari UUHT, seharusnya tidak bertentangan dengan peraturan diatasnya sesuai dengan asas lex superior derogate legi inferiori, berarti bahwa ketentuan dibawahnya tidak boleh bertentangan dengan ketentuan diatasnya. Mengingat masih adanya akta pembebanan hak tanggungan yang tidak mencantumkan klausula roya partial. hal tersebut menimbulkan masalah ketika debitur telah melunasi sebagian hutangnya kepada kreditur meskipun oleh pihak kreditur telah mengeluarkan surat keterangan roya partial hak tanggungan, namun pelaksanaan roya tersebut akan ditolak oleh kantor pertanahan karena pihak kreditur tidak memberikan perincian nilai dari masing-masing tanah yang menjadi obyek hak tanggungan 
sedangkan apabila tidak dirinci maka secara otomatis juga tidak dimungkinkan untuk melaksanakan roya partial.

\section{DAFTAR PUSTAKA}

\section{Buku}

Harsono, Boedi. 2008. Hukum Agraria Indonesia: Sejarah Pembentukan Undang-Undang Pokok Agraria, Isi, Dan Pelaksanaannya. Jakarta: Djambatan.

Kasmir. 2000. Bank Dan Lembaga Keuangan Lainnya. Jakarta: PT. Raja Grafindo Perkasa.

Marzuki, Peter Mahmud. 2011. Penelitian Hukum. cet 11. Jakarta: Kencana.

ND, Mukti Fajar ND dan YuliantoAchmad. 2013. Dualisme Penelitian Hukum Normatif Dan Empiris. Yogyakarta: Pustaka Pelajar.

Parlindungan. 1996. Komentar Undang-Undang Tentang Hak Tanggungan Atas Tanah Beserta

Benda-Benda Yang Berkaitan Dengan Tanah. Bandung: Mandar Maju.

Ranggawidjaja, Rosjidi. 1998. Pengantar Ilmu Perundang Undangan Indonesia. Bandung: CV Mandar Maju.

Salim, HS. 2007. Perkembangan Hukum Jaminan Di Indonesia. Jakarta: Raja Grafindo Persada.

Soekanto, Soerjono Soekanto \& SriMamudji. 2001. Penelitian Hukum Normatif (Suatu Tinjauan Singkat). Jakarta: Rajawali Pers,.

Soeprapto, Maria Farida Indrati. 1998. Ilmu Perundang-Undangan. Yogyakarta: Kanisius.

Sudrajat, Sutardja. 1997. Pendaftaran Hak Tanggungan Dan Penerbitan Sertifikatnya. 1997:

Mandar Maju.

Sutedi, Adrian. 2010a. Hukum Hak Tanggungan. Jakarta: Sinar Grafika.

. 2010b. Hukum Perizinan Dalam Sektor Pelayanan Publik. Jakarta: Sinar Grafika.

Suteki dan GalangTaufani. 2018. Metode Penelitian Hukum: Filsafat, Teori Dan Praktik. Ed, Cet 2.

Jakarta: Rajawali Pers

Tambunan, Toman Sony dan Wilson R.G. Tambunan, 2019. Hukum Bisnis. Jakarta: Prenadamedia group.

Usman, Rachmadi. 2008. Hukum Jaminan Keperdataan. Jakarta: Sinar Grafika.

Waskito dan Hadi Arwono,. 2017. Pertanahan, Agraria, Dan Tata Ruang. Jakarta: Kencana.

\section{Artikel Jurnal}

Kinanti, Karenandria Pradnya. 2012. "Roya Partial Terhadap Jaminan Hak Tanggungan Dalam Praktek Di Kantor Pertanahan Kota Semarang.” vol 1 no 4. 
Risa, Yulia. 2017. "Perlindungan Hukum Terhadap Kreditur Atas Wanprestasi Debitur Pada Perjanjian Kredit Dengan Jaminan Hak Tanggungan.” Jurnal Normative Vol.5,.

Sagita, Mega Ria. 2016. "Pelaksanaan Roya Partial Hak Tanggungan Menurut Undang-Undang Nomor 4 Tahun 1996 Tentang Hak Tanggungan Di Kantor Pertanahan Kota Semarang.” 5 no 2:

Sudibyo, Efty Hindaru. 2017. "Peran Notaris Dalam Pembuatan Akta Izin Roya Hak Tanggungan Karena Hapusnya Hutang Dalam Perspektif Kepastian Hukum.” Vol 4 no 2.

\section{Undang-undang dan Peraturan}

Kitab Undang-Undang Hukum Perdata

Undang Undang No. 5 Tahun 1960 Tentang Peraturan Dasar Pokok Agraria

Undang-Undang No. 4 Tahun 1996 Tentang Hak Tanggungan Atas Tanah Beserta Benda-Benda Yang Berkaitan Dengan Tanah

Undang-Undang No. 12 Tahun 2011 tentang Pembentukan Peraturan Perundang-Undangan Peraturan Menteri Negara Agraria/ Kepala Badan Pertanahan Nasional Nomor 3 Tahun 1997 tentang Ketentuan Pelaksanaan Peraturan Pemerintah Nomor 24 Tahun 1997 tentang Pendaftaran Tanah 